\title{
Piotr Bogalecki*
}

iD https://orcid.org/0000-0002-6527-9765

\section{Możliwości partytury - możliwości poezji. Schäffer i Wirpsza'}

W opublikowanym w 1965 roku eseju Gra znaczeń - który uznać dziś można za jeden z najważniejszych dokumentów kształtowania się neoawangardowej metaświadomości polskiej poezji - składa Witold Wirpsza hołd muzyce, określając ją mianem „wielkiej mistrzyni ironii”2. Jako „rozległa pozapojęciowa dziedzina oznaczonych wyznaczonych dźwięków” potrafi się ona wszakże „tym, co pozapojęciowe, swymi niesemantycznymi ideogramami (bo czymże jest zapis nutowy?) świetnie zabawiać”3. Jak pisze poeta, zabawę tę w dużej mierze umożliwia rozziew między dynamiką „doczesnego” przebiegu kompozycji a „wiekuistością zapisu”, czy też - jak powie nieco dalej - „równoczesnością wszystkich nut utworu”. Nawiązując do etymologii fugi, stwierdzi Wirpsza: „Rezultatem popłochu, paniki, ucieczki, napiętej ruchliwości, dramatycznej dynamiki jest rzecz statyczna: zapis"5 - a rozpoznanie to stanie się początkiem jego eksperymentu z partyturą.

* Dr hab. adiunkt; Uniwersytet Śląski w Katowicach, Katedra Literatury Porównawczej; Plac Sejmu Śląskiego 1, 40-032 Katowice; e-mail: piotr.bogalecki@us.edu.pl

1 Praca powstała w wyniku realizacji projektu badawczego $\mathrm{nr}$ 2014/15/D/HS2/03006 finansowanego ze środków Narodowego Centrum Nauki.

2 Witold Wirpsza, Gra znaczeń, w: tegoż, Gra znaczeń. Szkice literackie, Państwowy Instytut Wydawniczy, Warszawa 1965, s. 237. Za ważny kontekst rozważań Wirpszy przedstawionych w Grze znaczeń (w którym to zbiorze zamieścił on aż dwa eseje o Tomaszu Mannie) uznać należy Doktora Faustusa, kilka lat wcześniej przełożonego przez niego wspólnie z żoną, Marią Kurecką; w liście do Kretzschmara pyta wszak Leverkühn na przykład: „Czemu zdawać mi się musi, jakoby prawie wszystkie, więcej, wszystkie środki i konwencje sztuki nadawały się dziś już tylko do parodii?" (Tomasz Mann, Doktor Faustus, przeł. M. Kurecka, W. Wirpsza, Muza, Warszawa 2012, s. 137).

3 Witold Wirpsza, Gra znaczeń, dz. cyt., s. 237.

4 Tamże, s. 238-239.

5 Tamże, s. 238. 
Zauważając, że „fugę fortepianową z Wohltemperiertes Klavier Jana Sebastiana Bacha, rozpiętą na dwóch stronicach druku nutowego w formacie quarto, można objąć jednym rzutem oka” i dopowiadając, że „przy pewnej wprawie wystarczy taka kontrola ad oculos, całościowa, [...] żeby się dowiedzieć, co się w tym zapisie muzycznie dzieje" - proponuje poeta „włączyć [...] mechanizm zwiększający dystans; potęgujący ironię; oko należy oddalić tak, aby zapis popłochu (fugi) stał się jednym i jednorodnym znakiem; ideogramem; symbolem takim, jak symbol matematyczny"?. Jak się okazuje, już przeprowadzanie tego typu prostej operacji, zrównującej z sobą zapis nutowy i naukowy, otworzyć może nowe twórcze możliwości; oto wszakże „obydwoma na taką samą modłę można [...] operować, z przekorą, samowolą, arbitralnością?" Nie na tym jednak koniec: „oto przy jeszcze większym oddaleniu oka [...] zapis staje się plamą" - muzyka zapisana za pomocą ciągu posiadających konkretne znaczenia, konwencjonalnych znaków przeobraża się w obraz: „Ze wzorzystości, z gąszczu, z gmatwaniny tego uplamienia popłoch podejrzliwości zaczyna zamiast formuł wyłuskiwać obrazowość"’. W tekście Wirpszy jest to moment wyraźnego uaktywnienia funkcji poetyckiej - oto w jego gawędziarskim do tej pory tekście zaczyna się nagle aż roić od środków stylistycznych, a o muzycznej notacji zaczyna mówić się z niezwykłą wprost metaforycznością:

Ekspozycja tematu fugi staje się w popłochu podejrzliwości szeregiem błotnych śladów gadzich; bryłowata zawartość stretta gnilnym roślinnieniem parującego pobrzeża; zarysy figuratywnych grupek gronami bakteryjnych kolonii na grząskiej pożywce; i nie spostrzegamy się, kiedy z zapisu, rozpiętego na dwóch stronach papieru nutowego, robi się duszna i parna obrazowa plamistość, wiodąca nas i naszą wyobraźnię wstecz, ku ledwo zorganizowanym białkom organicznym naszego początku: nie znajdziemy tam ani portretu renesansowego, ani holenderskiego krajobrazu, ani wizerunku rozcapierzonej symetrii motylej struktury. Odwrócona luneta ironizacji odwróciła ruch historyczny ku degeneracji; od chłodnej trzeźwości ku wilgotnej ciepłocie egzystencjalnego trzęsawiska. Gdyż kryje się za tym wszystkim, w całej swej rozwiązłości, lęk o istnienie; trwoga i dygotanie ${ }^{10}$.

Punkt dojścia tego nietypowego odczytania partytury nie może nie zadziwiać; coraz bardziej odsuwając od niej oko, wydaje się wszak widzieć Wirpsza przebieg biologicznych i kulturowych procesów ewolucyjnych: aż do „ledwo zorganizowanych białek organicznych naszego początku" z jednej i aż do targanego kierkega-

\footnotetext{
6 Tamże.

7 Tamże, s. 239.

8 Tamże.

9 Tamże, s. 240.

10 Tamże, s. 240-241.
} 
ardowskim lękiem o istnienie „egzystencjalnego trzęsawiska” z drugiej strony. Tak jakby partytura potrafiła powiedzieć poecie rzeczy, o których nie śniło się muzykom i muzykologom...

\section{Przemiany notacji muzycznej a eksperymenty powojennej awangardy poetyckiej}

Opowiedzianą przez Wirpszę przygodę z partyturą uznać można za modelowy przykład gestu, który stał się udziałem części powojennych poetów polskich - tak różnych, jak chociażby Marian Grześczak, Andrzej Partum czy Stefan Themerson - którzy w swoich eksperymentach literackich na różne sposoby zwracali się ku problemom uwidocznionym przez dwudziestowieczne przemiany notacji muzycznej. Jak wiadomo, ostatnie stulecie, zwłaszcza zaś jego druga połowa, to czas, w którym - jak ujął to Bogusław Schäffer - notacja muzyczna „nieprzewidywalnie wybiegła poza wczorajsze konwencje i dąży niemal do barokowego bogactwa”, przynosząc bujny rozrost rozmaitych form muzycznego zapisu i jego nowe funkcje, a w końcu „niezwykłą niespodziankę: autonomię dzieła muzycznego w postaci partytury”"1. I chociaż dziś nabraliśmy do nich pewnego dystansu, nie sposób nie zgodzić się $\mathrm{z}$ kompozytorem, iż rozrost ów - w pewnym okresie wyraźnie zmierzający w stronę muzyki graficznej - nie był jedynie ekstrawagancją, lecz „rezultatem rozwoju samej muzyki"'12. Mowa tu, rzecz jasna, nie tylko o muzyce elektronicznej czy konkretnej, z oczywistych względów i wręcz z definicji wymagających odmiennego zapisu, ale przede wszystkim o szerokim spektrum nowych technik kompozytorskich, takich jak chociażby aleatoryzm czy serializm, które wszakże - jak ujmował to Carl Dahlhaus - narzuciły notacji warunki, w których przy zastosowaniu tradycyjnych środków podstawowy dla niej „postulat” jasności „stał się trudny do realizacji”" Nie przez przypadek zatem w Grze znaczeń tuż przed sięgnięciem po partyturę, przypomni Wirpsza założenia „muzyki serialnej” - „ażeby”, jak stwierdzi, „dojść niektórych rzeczy podstawowych"14. Parafrazując poetę, powiedzieć moglibyśmy, że niebywały rozrost rozmaitych form notacji muzycznej właściwy dla lat pięćdziesiątych i sześćdziesiątych XX wieku służyć miał temu samemu - stanowił próbę dotarcia do tego, co w muzyce najbardziej podstawowe, fundamentalne. Bardziej zatem niż narzucić chciał jako uniwersalną określoną nową formę zapisu nutowego, uwidaczniał on fakt istnienia notacji jako takiej, jej historyczność i konwencjonalność, a co za tym idzie także i ograniczenia - lecz z drugiej strony

11 Bogusław Schäffer, Mały informator muzyki XX wieku. Wydanie nowe, Polskie Wydawnictwo Muzyczne, Kraków 1967, s. 70, 78. 
również nowe możliwości, jakie wytworzyć może praca nad (oraz z) nową partyturą. Także Wirpsza poszukuje inspiracji w nowym, nietradycyjnym wykorzystaniu notacji, której konwencjonalność obnaża i artystycznie wyzyskuje; nie interesuje go też przy tym partytura jednostkowej, konkretnej kompozycji - czyli sytuacja odniesienia intersemiotycznego, której dotyczy zaproponowane przez Andrzeja Hejmeja pojęcie partytury literackiej ${ }^{15}$. Zamiast po Das Wohltemperiertes Klavier sięgnąć mógłby poeta po zapis nutowy jakiejkolwiek innej fugi, zajmuje go wszak notacja muzyczna jako taka - i możliwości, jakie daje jej odczarowanie czy, jeśli kto woli, dekonstrukcja, odsłonięcie materialności, jej analiza jako ciągu znaków, zapisu, pisma. W swoim tekście postępuje Wirpsza podobnie do wielu artystów wizualnych i twórców poezji konkretnej, którzy - jak na przykład Luciano Ori (chociażby w cyklu Poesia visiva z 1972), Milan Grygar (np. w pracach z serii Linear Score) czy Gerard Rühm (w realizacjach składających się na cykle Visuelle Musik, Auditive Poesie i inne) - wyzyskują sam kształt notacji muzycznej, jej stronę wizualną i specyficzną organizację przestrzeni. Działań takich, wykraczających często w stronę konceptualizmu, nie należy degradować do rangi efekciarskich igraszek - z ich pomocą wymienieni artyści przesuwali historycznie zdefiniowane granice sztuk i w serii eksperymentów badali możliwości powstających w ten sposób intermediów. Z kolei, Wirpsza dzięki eksperymentowi z partyturą polemizuje z zachowawczymi odbiorcami literatury i sztuki, określanych przez siebie mianem „teoretyków sentymentalnych”, a pozbawionych, jak powiada, „poczucia humoru; obserwują [oni] nunc stans z pozycji nunc fluens i mają za złe"16. W przeciwieństwie do nich teoretycy i praktycy nowej sztuki spoglądają na „wiekuistość zapisu” z uwagą i nadzieją, próbując wyzyskać ożywcze napięcie pomiędzy nunc stans a nunc fluens. W pewnym sensie uczą się oni zatem czytania partytur: tyle tylko, że na nowo, ironicznie, a zatem - przynajmniej zdaniem Wirpszy - poetycko. Nie przez przypadek tytuł jednego z podrozdziałów Gry znaczeń, w których opisuje on swój eksperyment z partyturą nosi wymowny tytuł Nauka czytania.

Mniej więcej w tym samym czasie, w którym Wirpsza kończył korektę Gry znaczeń, Bogusław Schäffer pracował nad drugą, znacznie rozszerzoną wersją, swojego Małego informatora muzyki XX wieku („małego” być może rozmiarami,

15 Zgodnie z definicją pojęcie krakowskiego komparatysty oznacza „partyturę muzyczną, która w pewien sposób implikuje konkretny tekst literacki [i] w rezultacie zachodzących uwarunkowań intertekstualnych [...] okazuje się [...] konieczna dla tegoż tekstu jako macierzysty kontekst interpretacyjny" (Andrzej Hejmej, Partytura literacka, w: tegoż, Muzyka w literaturze. Perspektywy komparatystyki interdyscyplinarnej, Universitas, Kraków 2012, s. 62). Hejmej precyzuje, że nie idzie tu o partyturę jako taką, o „wszelkie detale i subtelności [...] muzycznego zapisu”, lecz wyłącznie o „aspekt ontologiczny [...] konkretnego dzieła muzycznego", stanowiący o jego „rozpoznawalności [i] niezmienności w sensie fizycznym” (tamże, s. 62).

Witold Wirpsza, Gra znaczeń, dz. cyt., s. 255. 
lecz bynajmniej nie wpływem, jaki wywarł na nadwiślańską znajomość muzycznej awangardy). Pochylając się nad „współczesną partyturą" i podkreślając szereg „różnic [...] dzielących” ją od „partytur wcześniejszych”, konstatował Schäffer:

A zatem czytanie partytury nie jest już «wewnętrznym» sporządzaniem wyciągu, lecz czytaniem i rozumieniem partytury. I tak jak przy czytaniu tekstu literackiego czytanie i rozumienie muszą iść z sobą w parze, tak i tu nie wolno tych rzeczy rozdzielać ${ }^{17}$.

Tak zatem, jak Wirpsza poszukując inspiracji dla nowej poezji, przybliża oko do partytury (czy właściwie - oddala je od niej), tak Schäffer, próbując opisać partytury nowej muzyki, pochyla się nad tekstem literackim. Nie przeceniając tej zbieżności, uznać trzeba, że jest ona pod wieloma względami znamienna i to bynajmniej nie wyłącznie z tego powodu, że dotyczy jednego z najbardziej nowatorskich poetów i jednego z najbardziej nowatorskich kompozytorów polskiej neoawangardy. W swoim ważnym tekście Interferencje muzyki i poezji a wspótczesna notacja, którego przekład ukazał się w 1972 roku w znanym i uznanym periodyku „Res Facta”, postulował Gillo Dorfles konieczność łącznego rozpatrywania przemian obu wymienionych w tytule jego artykułu sztuk. Przekonując, że „dzisiejsza komplikacja i zmienność notacji muzycznej - która, jak wiadomo, osiąga często granice ongiś niewyobrażalne - nie może pozostawać bez związku z analogiczną ewolucją w innych dziedzinach sztuki" ${ }^{\prime \prime}$, wskazywał włoski filozof przede wszystkim na coraz to bliższe relacje poezji, muzyki i malarstwa:

Nie ulega wątpliwości, że równolegle $\mathrm{z}$ „umuzycznieniem” i wizualizacją przejawiającą się w poezji począwszy od utworów Verlaine’a, a bardziej jeszcze (z uwagi na aspekt graficzny) w utworach Mallarmégo, futurystów, Majakowskiego etc., mamy do czynienia z postępującą złożonością graficzno-malarską i „literacką" w zapisie muzycznym. Nie będzie w tym nic dziwnego, jeśli weźmie się pod uwagę, że zapis muzyczny przechodził wielokrotnie przez analogiczne okresy „kryzysu semiotycznego"'19.

Jedna z etymologii greckiego słowa kryzys odsyła nas do sztuki lekarskiej, określając krytyczny moment rozwoju choroby domagający się natychmiastowego postawienia diagnozy i działania. W narracji Dorflesa działaniem takim jest „interwencja «wizualizacji» w dziedzinę «sztuki czasowej«", dokonująca się zarówno

17 Bogusław Schäffer, Mały informator..., dz. cyt., s. 79.

18 Gillo Dorfles, Interferencje muzyki i poezji a współczesna notacja, przeł. Maria Wodzyńska, „Res Facta" 1972, nr 6, s. 215.

19 Tamże, s. 217-218. 
$\mathrm{w}$ „najnowszych eksperymentach z zakresu poezji konkretnej” (wymienia tu on m.in. twórczość takich autorów, jak Kriwet, de Melo e Castro, de Campos, Gombringer, Rot, Spatola), jak i w partyturach serializmu, Bouleza czy - „w sposób jeszcze bardziej wyrazisty” - Stockhausena ${ }^{20}$. Jak zauważa włoski filozof, „kolisty" i ,rotacyjny” zapis takich kompozycji tego ostatniego, jak Refrain z 1959 roku, „Z czysto graficznego punktu widzenia wykazuje zdumiewające punkty styczne z niektórymi eksperymentami "poezji wizualnej» Kriweta" ${ }^{21}$. W interesującym nas okresie poezja i muzyka wydawały się zatem podążać wspólną drogą, wiodącą „ku ikoniczności” (jak powie Dorfles, zauważywszy, że „dziś muzyka po części uwolniła się od słowa”, a „poezja zbliżyła się raczej do malarstwa niż do muzyki”), a także (jak zaproponuje chwilę później, po uwzględnieniu rosnącej roli happeningu i sztuki takich artystów, jak Rauschenberg, Chiari czy Lambert) - „ku «działaniu» (action), ku widowiskowości lub - by być bardziej dokładnym - ku wizualizmo wi kinetycznemu i przedmiotowemu"22.

W opublikowanym w 1968 roku eseju Poezja a muzyka opowiada Wirpsza o rozmowie ze swoim „dobrym znajomym, jednym z najwybitniejszym współczesnych kompozytorów polskich"23 ${ }^{\text {, }}$ który zwrócił się do niego z prośbą o pomoc w odnalezieniu tekstu poetyckiego, jaki pozwoliłby mu zrealizować jedno z jego kompozytorskich zamierzeń. Tekst ów miałby być „komunikatywny, ale niezrozumiały”24, co staje się dla Wirpszy pretekstem do porównania dawnych, „pieśniowych” form koegzystencji słowa i muzyki oraz ich współczesnych przekształceń, próbujących wypracować ,język artystyczny, będący językiem i muzycznym, i poetyckim zarazem”, czyli „w gruncie rzeczy nową dyscyplinę artystyczną"25. Chociaż poeta dystansuje się od możliwości jej „odnalezienia” - i trudno byłoby też uznać, że pod tak akurat sformułowanym postulatem podpisałby się Schäffer (podobnie, jak nie sposób rozstrzygnąć, czy to on jest bohaterem przytoczonej anegdoty $\left.{ }^{26}\right)$ - powiedzieć można z pewnością, że obu twórców interesowało poszukiwanie „Związków strukturalnych” poezji i muzyki poza „z pozoru oczywistymi”, a w istocie „zwodniczymi” ich podobieństwami (wylicza poeta: „zwodnicza jest eufonia, zwodniczy jest nastrój, zwodniczy jest nawet rytm, choć jemu przypada rola organizująca" ${ }^{27}$.

20 Tamże, s. 218.

21 Gillo Dorfles, Interferencje muzyki..., dz. cyt., s. 218.

22 Tamże, s. 220.

23 Witold Wirpsza, Poezja a muzyka, w: Ruchome granice. Szkice i studia, red. Marian Grześczak, Gdynia 1968, s. 179.

24 Tamże, s. 180.

25 Tamże, s. 186.

26 Leszek Szaruga - któremu bardzo dziękuję za tę i inne sugestie pomocne w pisaniu artykułu - przypuszcza, że może chodzić raczej o Witolda Lutosławskiego bądź Kazimierza Serockiego.

27 Witold Wirpsza, Poezja a muzyka, dz. cyt., s. 185. 
Zdaniem Wirpszy związki takie „wykrywalne są w zasadzie jedynie poprzez [...] idealizację, poprzez język zbliżony do sformalizowanego, a więc poprzez język trzeci, nieartystyczny, poprzez język w swej nieartystyczności pośredniczący"28. Czytelników opublikowanej trzy lata wcześniej Gry znaczeń nie będzie dziwił fakt, że w tym miejscu zaprosi Wirpsza do gry ironię („wiadomo [...], że wszelki proces pośredniczący jest zarazem procesem ironizującym, stwarzającym dystans i wzajemne zrozumienie"), w związku z czym „organiczny, zdawałoby się, związek między muzyką a poezją, nawet taki, który zachodzi w prostej pieśni ludowej” okazuje się „Związkiem ironicznym”, gdyż „między tekst a melodię zakradł się nieartystyczny pośrednik, który uniemożliwia pełny styk obu elementów, muzycznego

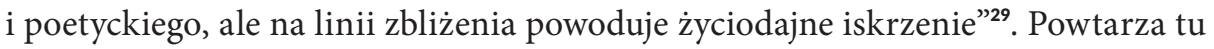
Wirpsza niejako diagnozę z zakończenia Gry znaczeń, w której to właśnie napięcie pomiędzy nunc fluens a nunc stans umożliwiało tworzenie. Założyć można, że jeśliby za interesujący go ,język pośredniczący” spróbować, za Dorflesem, uznać obraz, sytuacja nie uległaby zmianie - to nieredukowalna różnica pomiędzy porządkami ikonicznym, werbalnym i dźwiękowym stanowiłaby o największej produktywności podejmowanych na ich styku intermedialnych eksperymentów. Żeby jednak prawdziwie „zaiskrzyło”, musiałyby one - choćby na krótko - gwałtownie się do siebie zbliżyć.

\section{Pierwszy polski konkretysta? Litery Schäffera}

Ze zrozumiałych względów dla badacza poezji nieco mniej interesujące wydawać się mogą iskry lecące spod kolejnych prac Schäffera - nietworzącego akurat (a przynajmniej nie publikującego ${ }^{30}$ ) osobnych utworów poetyckich, a jedynie przybliżającego się do sztuki słowa w swoich tekstach dla teatru. Te ostatnie doczekały się licznych omówień, w których uwagę badaczy zwracała przede wszystkim ich „swoiście głęboka” muzyczność, „odbierana poprzez intelektualną refleksję", a manifestująca się $\mathrm{w}$ przeprowadzanych $\mathrm{z}$ „pominięciem płaszczyzny stylistycznej” licznych „zabiegach umuzycznienia tekstu”"31. Niezależnie od tego, czy uznamy twórczość tę aż za „swoistą aneksję teatru z perspektywy

28 Tamże.

29 Tamże.

30 Akurat w wypadku tak niestrudzonego eksperymentatora, jak Schäffer trudno bowiem o pewność - zwłaszcza, że przez lata pisał on „wielojęzyczną powieść” (Joanna Zając, Muzyka, teatr i filozofia Bogusława Schaeffera. Trzy rozmowy, Collsch Edition, Salzburg 1992, s. 163).

31 Marta Karasińska, Dialog, nie-dialog Bogusława Schaeffera, w: Bogusław Schaeffer. Kompozytor i dramatopisarz / Bogusław Schaeffer. Composer and playwright, red. M. Sugiera, J. Zając, Księgarnia Akademicka, Kraków 1999, s. 48. 
muzyki"32 , faktem pozostanie, że Schäfferowskie dramaty - jak podkreśla Joanna Zając - „przez długi czas egzystowały [...] na prawach utworów muzycznych”, a w ich obrąb sukcesywnie przenosił on szereg rozwiązań stosowanych w nowej muzyce (jak np. wykorzystywanie licznych wskazówek wykonawczych i określeń tempa, czy „traktowanie zjawiska czasu w kategoriach autonomicznego elementu formalnego"33). Bez wątpienia rację ma wszakże Andrzej Hejmej podkreślający, że twórczość autora Kwartetu dla czterech aktorów „znosi granice tzw. autonomicznych dziedzin sztuki”, w tym zwłaszcza „historycznie usankcjonowane granice między teatrem a muzyką" ${ }^{34}$. W istocie, obcując z twórczością Schäffera, znajdujemy się w samym sercu intermedialności: tekstów literackich, które „oparte zostały na strukturze partytury muzycznej”35; utworów muzycznych, które posiadają formę grafik czy kolaży; grafik, które wydają się partyturami ${ }^{36}$ itd. Można zatem przypuszczać, że także prymarna dla niego działalność kompozytorska nosić będzie ślady, choć z pewnością nie „aneksji”, to jednak, pewnej inspiracji ze strony literatury. Przywołujący postać Schäffera i zwracający uwagę na dokonujące się w jego twórczości przemiany notacji Jiř́ Valoch pisał o „literackości” partytur nowej muzyki, przejawiającej się chociażby w dbałości kompozytorów o „poetycką kompozycję swojego tekstu, często bardzo subtelnego i operującego precyzyjnym językiem, a przy tym lirycznego w ewokowaniu muzycznych sytuacji czy doznań" ${ }^{37}$. Chociaż tak rozumianą "niesentymentalną” poetyckość niełatwo uchwycić, wydaje się towarzyszyć ona wielu kompozycjom Schäffera, programowo wręcz poszerzającym możliwości dostępnych mu języków artystycznych; z pewnością wszak nie przez przypadek część z nich - jak np. wykorzystujący tekst Allena Ginsberga Howl (1966) - określał on w swoich partyturach jako „poetyckie”38. Warto pamię-

32 Andrzej Hejmej, Wokół Schaefferowskich partytur, w: tegoż, Muzyka w literaturze..., dz. cyt., s. 188. Joanna Zając, Multidymensjonalność w czasach niepewności, w: Bogusław Schaeffer..., dz. cyt., s. 18-19, 22; zob. też: Joanna Zając, Muzyka, teatr..., dz. cyt., s. 59.

34 Andrzej Hejmej, Wokół Schaefferowskich..., dz. cyt., s. 187-188.

35 Małgorzata Sugiera, Joanna Zając, Tytułem wstępu, w: Bogusław Schaeffer..., dz. cyt., s. 8.

36 Zob. np. Grafiki Bogusława Schaeffera. Sześćdziesięciolecie twórczości kompozytorskiej, red. J. Hodor, Państwowy Instytut Wydawniczy, Warszawa 2007.

37 Jiří Valoch, Partytury, przeł. Ewa Ciszewska, w: Dźwięki elektrycznego ciała/ Sounding the Body Electric, red. D. Crowley, D. Muzyczuk, Muzeum Sztuki, Łódź 2012, s. 118. Pisze Schäffer: „Kompozycję Howl należy traktować jako kompozycję poetycką, rodzaj monodramu dla recytatora i zespołu, którego zadaniem, według intencji autora, nie jest «towarzyszyć» recytatorowi, lecz tworzyć dla jego tekstu i gry - odpowiednią atmosferę" (Bogusław Schäffer, Howl dla recytatora i zespołu wykonawców wg Allena Ginsberga, Kraków 1974, s. 4). Równie „niesentymentalną" literackością cechuje się oparty na fragmencie Pałuby utwór TIS MW2, którego „wykonawcy powinni - nie czyniąc żadnych bezpośrednich aluzji do tekstu Irzykowskiego, ani też nie starając się dokonywać żadnych interpretacji tego tekstu - przekazać jednak swoim wykonaniem pewne wyobrażenia, które ten tekst implikuje" (Bogusław 
tać, że jest również Schäffer autorem słów do niektórych swoich utworów - jak np. Miniopera z 1988, Liebesblicke z 1990, czy Canti (Liebe und Nacht) z 2001 roku - a wyraźną literackością cechuje się również warstwa słowna pewnej grupy jego partytur, zwłaszcza tych spod znaku teatru instrumentalnego. Instrukcje wykonawcze z partytury głośnego TIS MW2 z 1963 roku wydają się wręcz poetycko umotywowane: ich postać determinuje bowiem występowanie w nich kolejnych liter (głosek) alfabetu, co zaznacza kompozytor podkreśleniami; na przykład w głosie pierwszego fortepianu, w części oznaczonej literą O odnaleźć można wskazówki: „obojętnie, obbiektywnie, z opanowaniem”, zaś w części D - „dużo drobnych motywów". W innych partiach - jak na przykład baleriny - instrukcje te, wciąż oparte na instrumentacji głoskowej, rozrastają się w dłuższe quasi-poetyckie komunikaty typu: „Minimalne ruchy i akcje, drobne ziarenka odruchów w małych wartościach czasowych [...] minimalne, ale wyraźne w tym minimum akcyjki - miniaturki!” (część M) czy „Raptowne ruchy, a raczej skoki - nagłe zaskakujące akcje o ostrym rysunku, gwałtownie zrywane” (część R). Do literatury zbliżał się zresztą Schäffer bardzo różnymi drogami: chociażby jako twórca muzyki do spektakli Józefa Szajny (m.in. do Fausta Goethego czy Zamku Kafki) ${ }^{39}$, jako autor „Dialogu audiowizualnego wyrażającego stosunek poezji i muzyki” przedstawionego na sesji Poezja wspótczesna i jej sąsiedztwo ${ }^{40}$, a w końcu jako autor słynnych Kodów na orkiestrę z 1961 roku, stanowiących zdaniem ich autora „pierwszy na świecie utwór napisany na maszynie do pisania, bez jednej wyrysowanej nutki”‘1. I chociaż już ten ostatni, warsztatowo-narzędziowy przykład ma z tradycyjnie pojmowaną literackością niewiele wspólnego, wydaje się, że w poszukiwaniu poezji w muzyce autora Tertium datur można (jeśli nie wręcz należy) zapuścić się jeszcze dalej - podążając śladem Dorflesa, zestawiającego kształt partytury Stockhausena $\mathrm{z}$ wierszami konkretnymi Kriwatera.

Oto partytura S.alto na saksofon altowy i solistyczna orkiestre kameralna z 1963 roku - już swoim polisemantycznym tytułem przywołująca obecność funkcji poetyckiej - okazuje się niezwykle interesująca właśnie z uwagi na zastosowany w niej wizualny eksperyment notacyjny. Mam na myśli zwłaszcza głosowy zapis

Schäffer, TIS MW2. Kompozycja sceniczna, Polskie Wydawnictwo Muzyczne, Kraków 1972, s. 4). Być może warto dodać w tym miejscu, że autorem niemieckiego tłumaczenia wykorzystanego w utworze fragmentu Pałuby, które zamieszczone zostało w partyturze, jest Wirpsza, nota bene stale współpracujący z Polskim Wydawnictwem Muzycznym (m.in. jako tłumacz tekstów w kompozycjach wspomnianego już Serockiego).

39 Zob. Jadwiga Hodor, Fenomen Schaeffera, w: Bogusław Schaeffer. Możliwości muzyki, red. M. Chotoniewski, Akademia Muzyczna w Krakowie, Kraków 2016, s, 192.

40 Marek Malinowski, Wokół Kłodzkich Wiosen Poetyckich, w: Zbliżenia. IX Kłodzka Wiosna Poetycka, wybór i oprac. B. Michnik, Powiatowy Dom Kultury, Kłodzko 1972, s. 11.

41 Joanna Zając, Muzyka, teatr..., dz. cyt., s. 144. 
drugiej części utworu, w której - jak czytamy w partyturze - zastosował Schäffer (nota bene, „po raz pierwszy” w swojej kompozytorskiej karierze) „czytany tekst jako materiał orkiestrowy" ${ }^{\text {"22 }}$. Dźwiękowa realizacja tego fragmentu, w którym członkowie trzydziestodwuosobowej orkiestry nieomal równocześnie, lecz bynajmniej nie chórem, czytają fragment Biesów Dostojewskiego (cztery pierwsze akapity drugiej części rozdziału II), przyjmować musi postać - jak określa to Adam Walaciński - „jakiegoś zrazu niezidentyfikowanego, dziwnego, podskórnego szumu, narastającego stopniowo aż do wrzawy” "43. „Szum” ten jednak w żaden sposób nie jest w stanie zadośćuczynić zastosowanej notacji - umotywowanej bynajmniej nie brzmieniowo, lecz wizualnie. W każdym głosie tekst Biesów przycięty został w inny sposób. Czynność tę rozumieć należy dosłownie, gdyż podział tekstu nie respektuje granic słów czy morfemów; jak bardzo często w poezji konkretnej ${ }^{44}$ ma on charakter maszynowy i traktuje tekst jako materiał - z którego tworzy Schäffer rozmaite figury geometryczne i układy wizualne. I tak, w głosie klarnetu basowego tekst przyjmuje kształt odwróconego domu, w głosie trzecich skrzypiec - zbliżonego do koła owalu, skrzypiec piątych - odwróconej „łzy”, pierwszej wiolonczeli - trzech „płomieni”, czwartej altówki - trójkąta i dwóch obłych kształtów, które układają się w całość nasuwającą na myśl kompozycje abstrakcjonistyczne. W niektórych głosach nakłada Schäffer na siebie fragmenty tekstu, stawiając pod znakiem zapytania możliwość jego głosowej realizacji, kiedy indziej (jak w partii harfy) wycina z niego określone kształty (trójkąta i półksiężyca), w końcu w większości głosów - na różne sposoby przycina tekst $\mathrm{z}$ boków, upodobniając osiągnięty przez siebie efekt do wycinanki. Tylko oboista dysponuje pełną wersją tekstu, a jedynie część instrumentalistów (jak piąta wiolonczela czy kontrabas) w pełni czytelnymi ich fragmentami, zaś niektórzy (jak druga trąbka) nie mają tekstu wcale - choć i w ich nutach widnieje komenda: „tekst/ read/ aż do końca tekstu”... Można by powiedzieć, że w realizacji dźwiękowej całe to wizualne zróżnicowanie, całe to ikoniczne bogactwo przepada bezpowrotnie - niedające się usłyszeć, stanowi osobliwość jedynie dla skonfundowanych wykonawców. Jeśli jednak - zgodnie z duchem czasu, w którym „nabierająca niezależności” notacja muzyczna stawała się „źródłem specyficznego doświad-

42 Bogusław Schäffer, S·alto na saksofon altowyisolistyczną orkiestrękameralna, Polskie Wydawnictwo Muzyczne, Warszawa 1965, s. 3.

43 Adam Walaciński, Salto 1963-1998. Dwa bieguny teatru instrumentalnego, w: Bogusław Schaeffer..., dz. cyt., s. 90.

44 Mowa tu zwłaszcza o wyodrębnionej przez Jerzego Jarniewicza odmianie poezji konkretnej, której ideałem byłby „wiersz całkowicie odsemantyzowany, a więc taki, w którym słowo przestało być znakiem, przestało symbolizować" - jak na przykład w Rubber-Stamp Poem Emmetta Williamsa (Jerzy Jarniewicz, Jabłko Picassa, czyli nieprzeźroczystość poezji konkretnej, w: tegoż, Od pieśni do skowytu. Szkice o poetach amerykańskich, Biuro Literackie, Wrocław 2008, s. 157). 
czenia artystycznego"45 - potraktuje się partyturę jako intermedium, stanowiące tyleż autonomiczną, co gotową wypowiedź artystyczną, eksperyment Schäffera nabrać może nowego znaczenia. Stwierdzić trzeba będzie bowiem, że - powstała w 1963 roku w orbicie oddziaływania najważniejszych eksperymentów powojennej awangardy - party tura S.alto stanowi pierwszy opublikowany przejaw polskiej poezji konkretnej, o dwa lata wyprzedzający druk pierwszych „wierszy nadsłownych” Mariana Grześczaka, a o trzy „poezjokształtów” Stanisława Dróżdża ${ }^{46}$, do tego zaś stanowiący właściwie nie pojedynczą realizację, lecz cały, przemyślany i konsekwentnie zrealizowany, cykl prac. Skoro wielu poetów konkretnych zachęca do dźwiękowej czy wręcz muzycznej realizacji swoich tekstów (między innymi wspomniany Grześczak, wyjaśniający, że w jego wierszach „pojedyncza litera występuje [...] często w roli nuty; taką nutę-głoskę można odtwarzać głosem i wtedy powstaje jakby poemat foniczny" ${ }^{\text {'47 }}$ - to dlaczego odmawiać mielibyśmy uznania funkcjonującego na podobnej zasadzie eksperymentu Schäffera za pierwszą polską konkretystyczną realizację tego typu? Spojrzenie na partytury jego autorstwa z perspektywy powojennej polskiej literatury eksperymentalnej wydaje się nie tylko uzasadnione, ale i wręcz konieczne, jeśli dąży się do uzyskania jej pełnego spektrum i obrazu kształtowania się. Z uwagi zaś na niespożytą inwencję autora Quattro movimenti uznać można, że otwiera ono przy tym nowe, rozległe pole badań; S·alto to wszak bynajmniej nie jedyna kompozycja jego autorstwa, zwracająca uwagę w kontekście eksperymentów konkretystycznych ${ }^{48}$.

45 Jiří Valoch, Partytury, dz. cyt., s. 112. Dopowie autor, że doświadczenie to „nie jest już związane z dźwiękową interpretacją, ale posiada dla "czytelników» specyficzny muzyczny charakter" (tamże).

46 Prawykonanie utworu odbyło się 13 maja 1963 na festiwalu Muzički Biennale Zagreb, zaś Polskie Wydawnictwo Muzyczne wydało partyturę dwa lata później. Por. Małgorzata Dawidek Gryglicka, Historia tekstu wizualnego. Polska po 1967 roku, Muzeum Współczesne Wrocław, Wydawnictwo Korporacja ha!art, Kraków-Wrocław 2012.

47 Marian Grześczak, Wiersze nadsłowne, w: tegoż, Wiersze wybrane, Czytelnik, Warszawa 1977, s. 245.

48 Interesującymi utworami byłyby tu na przykład „kompozycja foniczna” Creative Act czy Plakat muzyczny reprodukowane w monografii Joanny Zając (Dramaturgia Schaeffera, Collsch Edition, Salzburg 1998, s. 428, 320), jak również wykorzystujący technikę kolażową utwór Decomposizione na puzon, fortepian i aktora (1993). W stosunkowo tradycyjny, wykorzystujący pięciolinie zapis nutowy tego ostatniego wplótł Schäffer m.in. paradoksalne wskazówki typu: „(nic)” czy „Pianista nie wie, co ma grać, ale gra/ Nie wolno mu improwizować”, a także wykorzystywane często przez konkretystów, nawiązujące do prymitywnych odbitek i noszące ślady mechanicznej obróbki, polilinearne sekwencje liter i znaków interpunkcyjnych. Do nadrzędnej dla kompozycji tematyki, by tak rzec, dekonstrukcji nawiązuje również napisany przez samego Schäffera tekst dla aktora rozpoczynający się od słów: „Czy państwo wiecie, co to jest destrukt. Destrukt to w języku bankowców pieniądz papierowy, z powodu nieczytelności cyfr i podpisu dyrektora wycofany z obiegu" (Bogusław Schäffer, Decomposizione, w: Grafiki Bogusława..., dz. cyt, s. 21-22). 


\section{Poezja i partytura? Próby (nie) do wykonania}

Być może na tle niekończących się eksperymentów Schäffera (które nie bez złośliwości nazywano wszak ,awangardą awangardy"49), poetycka twórczość Wirpszy wypaść może blado. Tak jednak jak w jego, rozpoczynającym niniejszy artykuł, przykładzie z partyturą - wszystko zależy od tego, jak spojrzeć. W 1960 roku, czyli pięć lat przed Grą znaczeń, opublikował on poemat Don Juan, którego „środki wyrazu” - jak wyznawał w dołączonym do niego komentarzu - „zapożyczone” zostały „w pewnej mierze [...] z muzyki”, zwłaszcza zaś z „muzyki polifonicznej”:

zawsze, ilekroć [...] patrzyłem na jej zapis nutowy, konstrukcja utworu układała mi się w diagram, w obraz graficzny, w precyzyjnie narysowany wykres o nałożonych na siebie kilku funkcjach. Owo rzutowanie rozciągłości w czasie na graficzną równoczesność było bardzo kuszące, choć naturalnie literacko nie do wykonania; niemniej postanowiłem dokonać w Don Juanie tego typu próby ${ }^{50}$.

Wirpsza wskazuje w tym miejscu na kończącą poemat część o Nuharpiartetaku, w której stosować miał „ostrożną "polifonię zdań«”, oraz na fragment Modliszki. Prorokini głodu, w którym posługiwał się swoistym „odpowiednikiem basso

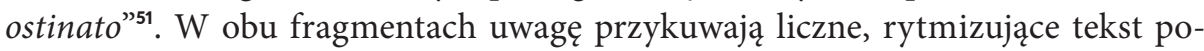
wtórzenia oraz sugerujący wielogłosowość nawiasowy zapis części tekstu (oba te rozwiązania - mające, jak można przyjąć, muzyczną proweniencję - szybko staną się jednymi z ulubionych środków poetyckich Wirpszy); we fragmencie o modliszce określoną grupę leksemów zapisywać będzie poeta ponadto rozstrzelonym drukiem. Najciekawszą jednak postać ma w Don Juanie otwierający go utwór Klomby kuliste, w którym wyśrodkowany tekst co rusz rozszczepia się na dwa, zapisywane w równoległych kolumnach głosy (określane jako Glosa I i Glosa II). Możliwość zobaczenia w Klombach kulistych swego rodzaju partytury kompozycji dwugłosowej nasuwać może nie tylko zawierająca muzyczne odniesienia treść utworu ${ }^{52}$, ale i jego, zachowane $\mathrm{w}$ archiwum poety, pochodzące $\mathrm{z}$ lat czterdziestych rękopisy, w których analizowany wiersz opatrzony jest tytułem Improwizacja na

49 Zob. J. Zając, Multidymensjonalność w czasach..., dz. cyt., s. 17.

50 Witold Wirpsza, Do czytelnika - przesłanie, w: tegoż, Don Juan, Państwowy Instytut Wydawniczy, Warszawa 1960, s. 60-61.

51 Tamże, s. 61.

52 Tekst - w którym czytamy m.in. o „grzmiącym echu”, „muzycznym falowaniu” czy „o w atmosferę wpiętym dźwięku” - kończy się następująco: „Trębacz trąbi na wzgórzach. Flety świszczą w kopułach./ Świat zamienia się w dźwięk.// Kiedyż kształty okrzepną?" (Witold Wirpsza, Klomby kuliste, w: tegoż, Don Juan, dz. cyt. s. 8). 
temat zadanych form ${ }^{53}$. Przywołując długą muzyczną tradycję, tytuł ten motywować mógłby specyficzny kształt utworu, próbujący, jak się wydaje, także wizualnie zaznaczyć „kulistość” w dostępnej poecie materii artystycznej.

Podobne muzyczne próby nie są u Wirpszy odosobnione; wiele jego tekstów - jak choćby cechujący się specyficzną, nasuwającą skojarzenia z wielogłosowością budową Traktat skłamany z 1968 roku - wydaje się realizować podobne zamierzenia. Fascynacja muzyką ma u autora Don Juana długą historię i o wiele lat poprzedza publikację - skądinąd wyraźnie muzycznego - debiutanckiego tomu Sonata z 1949 roku. Przed wybuchem wojny studiował bowiem Wirpsza w Wyższej Szkole Muzycznej w Warszawie i rozpoczął działalność koncertową; także w oflagu nosił się z zamiarem kontynuowania pianistycznej kariery, o czym świadczy m.in. zachowana korespondencja, $w$ tym list do jednego $z$ jego profesorów, kompozytora Ludomira Różyckiego ${ }^{54}$. Zrezygnowawszy w końcu z zawodu muzyka ${ }^{55}$, nie porzucił bynajmniej Wirpsza muzycznych zainteresowań, które wyraźnie odciskają się zarówno w na jego wyborach translatologicznych (m.in. Doktor Faustus Tomasza Manna, Bach Alberta Schweitzera, Wariacje na temat jazzu Joachima Ernsta Berendta), jak i w praktyce poetyckiej. Żywioł muzyczny wydaje się przenikać całe jego dzieło, stając się jednym z jego najważniejszych nurtów; zdaniem Dariusza Pawelca, „pasja muzyczna i powiązane z nią interferencje dźwięków, rytmów i formy poetyckiej realizują się u Wirpszy od początku na wielu poziomach wiersza: od brzmienia słów i ich ekwiwalencji, harmonii, do rozwiązań o charakterze strukturalnym, kompozycyjnym, podążania tropem muzycznej konstrukcji świata"56.

Pośród wielu „muzycznych” tekstów poetyckich Wirpszy szczególnie interesujący wydaje mi się odnaleziony w jego szczecińskim archiwum zapis obszernego udramatyzowanego poematu rozpoczynającego się od słów „Zwierzęta pociągowe". Włączony w obręb Faetona utwór ów, opatrzony tytułem Południe, przyjął dość tradycyjną postać tekstu dramatycznego, w którym wypowiadają się dwie postaci, Monolog i Dziecina; kolejne segmenty ich wypowiedzi są numerowane,

53 W obu odnalezionych rękopisach Klomby kuliste posiadają ponadto krótszą (niedokończoną?) część drugą określoną jako Utwór właściwy, z której publikacji Wirpsza najwyraźniej zrezygnował (Archiwum Witolda Wirpszy, Książnica Pomorska im. S. Staszica w Szczecinie, teczka $\mathrm{nr}$ 1436).

54 Zob. Witold Wirpsza, Listy z oflagu, oprac. D. Pawelec, Zaułek Wydawniczy Pomyłka, Szczecin 2015.

55 Zdaniem syna poety, Leszka Szarugi, stało się to konieczne z uwagi na konsekwencje ciężkiej pracy fizycznej wykonywanej przez poetę w pierwszym okresie pobytu w obozie jenieckim.

56 Dariusz Pawelec, Przedmowa, w: Witold Wirpsza, Sonata i inne wiersze do roku 1956, wybór i oprac. D. Pawelec, Instytut Mikołowski, Mikołów 2014, s. 16. 
wiemy więc, że Monolog wygłosić ma ich sto, Dziecina zaś - siedemdziesiąt pięćc ${ }^{57}$. Poszczególne (czasem dość obszerne) fragmenty poematu wydrukowane zostały majuskułą i wydają się stanowić - podobnie, jak w Don Juanie - jeszcze jeden, odrębny głos, bądź też sygnał odmiennej (głośniejszej, dobitniejszej) dźwiękowej realizacji tekstu. Natomiast w przechowywanym w archiwum - pozbawionym tytułu, zawierającym nieliczne skreślenia i, jak się wydaje, wcześniejszym ${ }^{58}$ - maszynopisie kolejnym wypowiedziom Monologu i Dzieciny towarzyszą dodatkowo umieszczone z lewej strony precyzyjne określenia czasu rzeczywistego, podobne do tych używanych w 45’ dla prelegenta Johna Cage'a z 1954 roku. Wymagają one od czytelnika stworzenia sobie w trakcie lektury pewnej mentalnej koncepcji wykonania tekstu, w której oba głosy nakładają się na siebie, tworząc to harmonijne, to kontrastujące $\mathrm{z}$ sobą współbrzmienia ${ }^{59}$. Wydaje się, że można potraktować archiwalną wersję Południa tyleż jako rodzaj (najpewniej niezrealizowanej) partytury poezji dźwiękowej, co jako partyturowy eksperyment, mający problematyzować czytelnicze przyzwyczajenia, literackie konwencje wypowiedzi monologowej i dialogowej, a w końcu - sam przebieg czasu. W 58. kwestii Dzieciny, której słowa wielokrotnie nawiązują do filozofii i religii, pojawia się zniekształcony fragment Heraklitejskiego aforyzmu „CZAS JEST CHŁOPCEM/ GRAJACCYM”, który dokończony zostanie w kwestii 59. („W GARDLANYM POPŁOCHU/ KORYTARZOWYM, GRAJĄCYM W/ KOŚCI”) - i stanowić będzie podstawę kolejnych permutacyjnych wypowiedzi, aż do ostatniej z nich, przyjmującej postać: „CZAS JEST CHŁOPCEM WŁADCZĄ/ GRĄ JA JESTEM W KOŚCI”. W wypowiedzi tej partnerująca Monologowi Dziecina objawia się zatem jako Czas - to on okazuje się więc jedynym słuchaczem naszych, kierowanych w pustkę oracji i tyrad... Także w Południu Wirpsza okazuje się więc ironistą - i to od pierwszych wersów, w których jednego z bohaterów swego konsekwentnie dialogowego, dwugłosowego tekstu nazywa Monologiem. W świetle tytułu i zawartości poematu podobnie ironiczny (pamiętajmy, że muzyka jest w tej materii „wielką mistrzynią”...) wydawać się musi „partyturowy” pomiar czasu: obaj mówcy rozpoczynają bowiem

57 Zob. Witold Wirpsza, Faeton, Instytut Mikołowski, Mikołów 2006, s. 52-79. W wersji przechowywanej w Archiwum Witolda Wirpszy (teczka nr 1440) mamy 99 wypowiedzi Monologu, zaś tekst już od pierwszych stron znacząco odbiega od wersji znanej z druku.

58

Ustalenie daty powstania omawianego maszynopisu nie jest łatwe (tym bardziej, że Faeton pisany był z przerwami przez trzydzieści lat aż do 1968 roku); na podstawie jego kształtu, stanu i porównania do innych podobnych dokumentów opatrzonych datami przypuszczać można jedynie, że powstał on w pierwszej połowie lat sześćdziesiątych.

59 O tym, że Wirpsza podkreślić pragnął brzmieniową warstwę swojego tekstu, świadczyć może włożona w omawiany maszynopis kartka zawierająca odnoszące się do niego adnotacje. Obok uwag podkreślających temporalny porządek utworu, jak „Godzina 11:oo”, znajduje się na niej następująca dyrektywa: „Uwaga: dopisać dźwięki” (Archiwum Witolda Wirpszy, teczka nr 1440). 
swoje wypowiedzi równo o jedenastej (w notacji poety: „11h00”), lecz czas wydaje się biec dla każdego z nich inaczej (przykładowo: swoją piątą kwestię kończy Monolog o 11h08, zaś Dziecina - o 11h03). Otwiera to możliwość nielinearnej lektury poematu (mogącej kojarzyć się z inspirującym chociażby Stefana Themersona zarazem „poziomym”, jak i „pionowym” czytaniem partytur $\left.{ }^{60}\right)$ - a zatem już nie tylko zgodnie z kolejnością druku poszczególnych wypowiedzi, lecz również na sposób „chronologiczny”, respektujący umieszczone przy nich określenia temporalne i „nakładający” na siebie mające rozbrzmiewać w tym samym czasie kwestie Monologu i Dzieciny. Tak zakomponowana całość wyraźnie ewokuje dwugłosową realizację utworu, zajmującą ściśle określoną ilość czasu (czyli godzinę - pierwsze kwestie Monologu i Dzieciny padają wszak o 11h00, zaś ostatnia w tytułowe południe, o 12h00), w której, dzięki zastosowanej notacji, regulowałby autor tempo podawania tekstu (od pewnego momentu wyraźnie się ono zwiększa; ostatnie wypowiedzi Monologu z godziny $12 \mathrm{~h} 00$ padać musiałyby już w bardzo szybkim, choć możliwym do osiągnięcia, rytmie).

Pozostawiając na inną okazję dokładniejszą analizę archiwalnej wersji Południa i pamiętając, że w ostatecznej, złożonej do druku wersji wyznaczniki jego „partyturowości” zostały zatarte, zapytać należałoby, czy podobnego charakteru nie próbował aby w pewnym momencie nadać Wirpsza całemu Faetonowi, a w związku z tym, czy zaproponowanego przez Zbigniewa Chojnowskiego metaforycznego porównania poematu do „swoistej partytury”"61 nie należałoby potraktować dosłownie. Pytania te wydają się zasadne nie tylko w obliczu niekompletności analizowanych zbiorów archiwalnych, lecz także z uwagi na stałą, choć często realizowaną pianissimo, „muzyczność” dzieła Wirpszy. Do ich postawienia zachęcać może również frapująca - bo z pewnością zaakceptowana przez poetę - Uwaga tłumaczki (Marii Kureckiej) zamieszczona w jego niemieckojęzycznym tomie bruchsünden und todstücke, opublikowanym w 1967 roku w redagowanej przez Maxa Bensego stuttgarckiej serii „rot”, a uznawanym za pierwszy przypadek „pol-

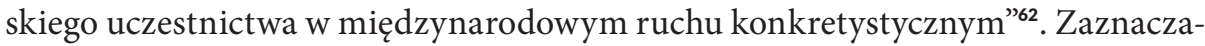
jąc, że zamieszczone w tomie teksty są jedynie „tłumaczeniami filologicznymi”o3

60 Zob. np. Stafan Themerson, Beyamus, w: tegoż, Generat Piesc i inne opowiadania, Czytelnik, Warszawa 1980, s. 70-71.

61 Zbigniew Chojnowski, O „Faetonie” oraz „Liturgii” Witolda Wirpszy, w: tegoż, Ku Tajemnicy. Szkice o poezji po 1956, Wydawnictwo Naukowe Uniwersytetu Warmińsko-Mazurskiego, Olsztyn 2003, s. 95.

62 Aleksandra Kremer, Przypadki poezji konkretnej. Studia pięciu ksiązek, Wydawnictwo Instytutu Badań Literackich PAN, Warszawa 2015, s. 329.

63 Zdaniem Kremer, opinia ta nie odpowiada prawdzie: „Analiza tłumaczeń wskazuje [...], że filologiczność tę trzeba by raczej rozumieć jako swego rodzaju niegotowość, surowość”, a „w tradycyjnej nomenklaturze [tłum. Kureckiej] byłoby [...] bliższe niedoskonałemu przekładowi literackiemu" (tamże, s. 315-316). 
i podając jako przykład nieadekwatność przekładu ostatniej części muzycznego wiersza Temat $z$ wariacjami i sonetem, napisze tłumaczka: „Można powiedzieć, że niemiecka wersja ma się do oryginalnej tak, jak w muzyce notacja funkcji harmonicznych do kompletnego zapisu nutowego" ${ }^{\text {"6 }}$. Czasem metafory wiedzą więcej - zaś w świetle zastosowanej w tomie typografii (ewokującej wielokolumnowość, a wręcz konstelacyjność wierszy Wirpszy) zastosowane porównanie może jawić się wręcz jako rodzaj - w przewrotny sposób usankcjonowanej przez autora - instrukcji lekturowej. W podobny sposób odczytywać można również fragment epilogu Featona, noszącego tytuł Próba samookreślenia, w którym, wykorzystując polisemię wyrazu „klucz”, napisze Wirpsza:

\section{[...] Następuje gwałtowne pomieszanie}

Składników, klucze zaś nieodmiennie są

Nieobecne i trzeba bez kluczy /jak nuty na

Nienakreślonej pięciolinii/ składać tekst: każdy

Ma sposobność odmiennego rozumienia zapisu ${ }^{65}$.

Nie tylko w kontekście powyższych rozważań wymowne wydaje się, że jako model implikowanej lektury swoich tekstów wybrał poeta tak bardzo niezdeterminowaną partyturę: bez kluczy, bez pięciolinii, bez instrukcji, jaka wskazywać mogłaby na ewentualne ograniczenia $\mathrm{w}$ „rozumieniu zapisu”... Podobnie jak możliwości notacji muzycznej Bogusława Schäffera, tak i poetyckie potencjalności prób Witolda Wirpszy wydają się tyleż niezdeterminowane, co nieograniczone.

\section{Bibliografia}

Chojnowski Zbigniew, O „Faetonie” oraz „Liturgii” Witolda Wirpszy, w: Zbigniew Chojnowski, Ku Tajemnicy. Szkice o poezji po 1956, Wydawnictwo Uniwersytetu Warmińsko-Mazurskiego, Olsztyn 2003.

Dahlhaus Carl, Notacja wspótczesna, przeł. Antoni Buchner, „Res Facta” 1970, nr 4, s. 92-108.

Dawidek Gryglicka Małgorzata, Historia tekstu wizualnego. Polska po 1967 roku, Korporacja Ha!art, Kraków-Wrocław 2012.

Dorfles Gillo, Interferencje muzyki i poezji a wspótczesna notacja, przeł. Maria Wodzyńska, „Res Facta” 1972, nr 6, s. 211-220.

64 Witold Wirpsza, bruchsünden und todstücke, tłum. M. Kurecka, E. Walther, Stuttgart 1967 [brak numeracji stron].

65 Witold Wirpsza, Faeton II, Instytut Mikołowski, Mikołów 2007, s. 113. 
Grafiki Bogusława Schaeffera. Sześćdziesięciolecie twórczości kompozytorskiej, red. Jadwiga Hodor, Państwowy Instytut Wydawniczy, Warszawa 2007.

Grześczak Marian, Wiersze nadsłowne, w: Marian Grześczak, Wiersze wybrane, Czytelnik, Warszawa 1977, s. 243-246.

Hejmej Andrzej, Partytura literacka, w: Andrzej Hejmej, Muzyka w literaturze. Perspektywy komparatystyki interdyscyplinarnej, Universitas, Kraków 2012, s. 59-79.

Hejmej Andrzej, Wokót Schaefferowskich partytur, w: Andrzej Hejmej, Muzyka w literaturze. Perspektywy komparatystyki interdyscyplinarnej, Universitas, Kraków 2012, s. 169-191.

Hodor Jadwiga, Fenomen Schaeffera, w: Bogusław Schaeffer. Możliwości muzyki, red. Marek Chołoniewski, Akademia Muzyczna w Krakowie, Kraków 2016, s. 191-201.

Jarniewicz Jerzy, Jabłko Picassa, czyli nieprzeźroczystość poezji konkretnej, w: Jerzy Jarniewicz, Od pieśni do skowytu. Szkice o poetach amerykańskich, Biuro Literackie, Wrocław 2008, s. 155-168.

Karasińska Marta, Dialog, nie-dialog Bogusława Schaeffera, w: Bogusław Schaeffer. Kompozytor i dramatopisarz / Bogusław Schaeffer. Composer and playwright, red. Małgorzata Sugiera, Joanna Zając, Księgarnia Akademicka, Kraków 1999, s. $45-70$.

Kremer Aleksandra, Przypadki poezji konkretnej. Studia pięciu ksiażek, Wydawnictwo Instytutu Badań Literackich, Warszawa 2015.

Malinowski Marek, Wokół Kłodzkich Wiosen Poetyckich, w: Zbliżenia. IX Kłodzka Wiosna Poetycka, s. 6-18.

Mann Tomasz, Doktor Faustus, przeł. Maria Kurecka, Witold Wirpsza, Muza, Warszawa 2012.

Pawelec Dariusz, Przedmowa, w: Witold Wirpsza, Sonata $i$ inne wiersze do roku 1956, s. 5-23.

Schäffer Bogusław, Decomposizione, w: Grafiki Bogusława Schaeffera. Sześćdziesięciolecie twórczości kompozytorskiej, red. Jadwiga Hodor, Państwowy Instytut Wydawniczy, Warszawa 2007, s. 22.

Schäffer Bogusław, Dzieje muzyki, Wydawnictwa Szkolne i Pedagogiczne, Warszawa 1983.

Schäffer Bogusław, Howl dla recytatora i zespołu wykonawców wg Allena Ginsberga, Polskie Wydawnictwo Muzyczne, Kraków 1974.

Schäffer Bogusław, Mały informator muzyki XX wieku. Wydanie nowe, Polskie Wydawnictwo Muzyczne, Kraków 1967.

Schäffer Bogusław, S.alto na saksofon altowy i solistyczna orkiestrę kameralną, Polskie Wydawnictwo Muzyczne, Warszawa 1965.

Schäffer Bogusław, TIS MW2. Kompozycja sceniczna, Polskie Wydawnictwo Muzyczne, Kraków 1972. 
Sugiera Małgorzata, Zając Joanna, Tytułem wstępu, w: Bogusław Schaeffer. Kompozytor i dramatopisarz / Bogusław Schaeffer. Composer and playwright, red. Małgorzata Sugiera, Joanna Zając, Księgarnia Akademicka, Kraków 1999, s. 5-9.

Themerson Stafan, Beyamus, w: Stafan Themerson, Generat Piesc i inne opowiadania, Czytelnik, Warszawa 1980, s. 5-114.

Walaciński Adam, Salto 1963-1998. Dwa bieguny teatru instrumentalnego, w: Bogusław Schaeffer. Kompozytor i dramatopisarz / Bogusław Schaeffer. Composer and playwright, red. Małgorzata Sugiera, Joanna Zając, Księgarnia Akademicka, Kraków 1999.

Wirpsza Witold, bruchsünden und todstücke, tłum. Maria Kurecka, E. Walther, Stuttgart 1967.

Wirpsza Witold, Don Juan, Państwowy Instytut Wydawniczy, Warszawa 1960.

Wirpsza Witold, Faeton, Instytut Mikołowski, Mikołów 2006.

Wirpsza Witold, Faeton II, Instytut Mikołowski, Mikołów 2007.

Wirpsza Witold, Gra znaczeń. Szkice literackie, Państwowy Instytut Wydawniczy, Warszawa 1965.

Wirpsza Witold, Listy z oflagu, oprac. Dariusz Pawelec, Zaułek Wydawniczy Pomyłka, Szczecin 2015.

Wirpsza Witold, Poezja a muzyka, w: Ruchome granice. Szkice i studia, red. Marian Grześczak, Wydawnictwo Morskie, Gdynia 1968, s. 175-186.

Valoch Jiř́, Partytury, przeł. Ewa Ciszewska, w: Dźwięki elektrycznego ciałal Sounding the Body Electric, red. David Crowley, Daniel Muzyczuk, Muzeum Sztuki, Łódź 2012, s. 110-119.

Zając Joanna, Dramaturgia Schaeffera, Collsch Edition, Salzburg 1998.

Zając Joanna, Multidymensjonalność w czasach niepewności, w: Bogustaw Schaeffer. Kompozytor i dramatopisarz / Bogusław Schaeffer. Composer and playwright, red. Małgorzata Sugiera, Joanna Zając, Księgarnia Akademicka, Kraków 1999, s. 11-26. Zając Joanna, Muzyka, teatr i filozofia Bogusława Schaeffera. Trzy rozmowy, Collsch Edition, Salzburg 1992. 


\title{
Piotr Bogalecki
}

\section{Możliwości partytury - możliwości poezji Schäffer i Wirpsza}

\author{
Streszczenie
}

Artykuł stanowi próbę porównania eksperymentalnych działań artystycznych kompozytora Bogusława Schäffera i poety Witolda Wirpszy podejmowanych niezależnie od siebie w latach 60. XX wieku. W dorobku tego pierwszego zwrócono uwagę na rolę i sposoby wykorzystania słowa w jego graficznych partyturach; postanowiono tezę, że partyturę S.alto na saksofon altowy i solistyczna orkiestrę kameralna z 1963 roku postrzegać można jako pierwszy w Polsce przykład poezji konkretnej. W dorobku Wirpszy omówiono przede wszystkim nawiązujący do nowych form notacji muzycznej poemat Południe odnaleziony w archiwum poety w Książnicy Pomorskiej w Szczecinie oraz poświęcone notacji muzycznej fragmenty ważnego dla polskiej neoawangardy literackiej eseju Gra znaczeń. Idąc za intuicjami Gillo Dorflesa, działania obu twórców omówiono jako intermedialne z ducha próby odpowiedzi na powojenny „kryzys semiotyczny”, na różne sposoby eksplorowany przez artystów europejskiej neoawangardy.

Słowa kluczowe: Bogusław Schäffer, Witold Wirpsza, poezja konkretna, poezja eksperymentalna, partytura, wiersz-partytura, muzyczność literatury, neoawangarda

\section{The Possibilities of Musical Score, The Possibilities of Poetry. Bogusław Schäffer and Witold Wirpsza}

\author{
Summary
}

This paper is an attempt to compare experimental artistic activities taken independently by the composer Bogusław Schäffer, and the poet Witold Wirpsza in the 1960s. In the works of the former the role and ways of using a word in his graphic scores are pointed out. It is argued that the score of Salto for Alto Saxophone and Chamber Orchestra of Soloists (1963) might be recognized as the first example of concrete poetry in Poland. As far as Wirpsza's work is concerned, two texts are discussed: a poem Poludnie (Noon), found in the archive in Książnica Pomorska 
in Szczecin, and referring to the new forms of musical notation; and an essay entitled Gra znaczen (The Game of Meanings), important for Polish literary neo-avantgarde, and its fragments dedicated to musical notation. Following the intuitions of Gillo Dorfles, both artists' activities are discussed as attempts to respond to postwar "semiotic crisis" previously explored in various ways by the artists of the European neo-Avantgarde.

Keywords: Bogusław Schäffer, Witold Wirpsza, Concrete poetry, Experimental poetry, Musical Score, Score-poem, Music and Literature, Neo-avant-garde

Piotr Bogalecki, dr hab., historyk i teoretyk literatury, adiunkt w Katedrze Literatury Porównawczej Uniwersytetu Śląskiego w Katowicach. Autor monografii „Niedorozmowy”. Kategoria niezrozumiałości w poezji Krystyny Miłobędzkiej (Warszawa 2011, Nagroda Narodowego Centrum Kultury) oraz Szczęśliwe winy teolingwizmu. Polska poezja po roku 1968 w pespektywie postsekularnej (Kraków 2016). Kieruje projektem badawczym NCN „Wiersze-partytury jako wyzwanie dla literaturoznawstwa: recepcja - reminiscencje - rewizje teoretycznoliterackie (na materiale polskiej poezji 1945-2010)". 